\title{
An Examination of the Causes of Unemployment among Youths in Nigeria
}

\author{
Galadima Gladstone Wayas, Sivapalan Selvadurai, Abd Hair Awang
}

\begin{abstract}
The rising youth unemployment in Nigeria is indeed disturbing as engagements of unemployed youths in armed robbery, kidnapping, Boko Haram, prostitution and other related social ills in Nigerian society are attributed to high rate of unemployment. The stated involvement in crimes by the unemployed youths does not only constitute social problems to the entire society but obstructs the development of the country. The main objective of this paper is to examine causes of youth unemployment in Nigeria as it relates mostly to moral bankruptcy in public leadership. Secondary sources were being used as the data for this study and it sets its analysis in the context of the neoliberal theory. The results of this study revealed that youth unemployment is caused mainly by corruption among the public office holders that has led to the degrading nature of infrastructures, security, and neglect of agriculture. This study therefore recommends among other things that Nigerian government ought to make its educational system self-reliance for the youths through the introduction of vocational and technical courses. Above all, Nigerian government should insist that its society has the enabling environment for business activities to thrive and that may as well accommodate investors and other businesses globally.
\end{abstract}

Keywords: Corruption, neoliberalism, Nigeria, poverty, youth unemployment.

\section{INTRODUCTION}

The International Labor Organization regards unemployment among youths as the whole populace of competent individuals residing in a community that were expected to be part of the economic and active persons however are staying with no [1] work and are likewise willing and accessible for employment. The suggestion of the above classification is that joblessness is the total number of persons within the working class and these are people among the ages of 18 and above years as required by the constitution of Nigeria, and these are making series of attempts and accessible for work within a stated or given time. This is not only a working class people who do not have work, however these are individuals that are interested and are vigorously look for and are very much accessible for the employment. Such a personality is duly fit for gainful work and has attained chains of applications or tried diverse recruitment chances but was not successful to secure any job [8].

The Federal Youth Program record of Federal Republic of Nigeria specifies the succeeding features for young persons:

Revised Manuscript Received on September 14, 2019.

Galadima Gladstone Wayas, School of Social, Development and Environmental, National University of Malaysia, Bangi, Selangor, Malaysia. (Email: galadimawayas@yahoo.com)

Sivapalan Selvadurai, School of Social, Development and Environmental, National University of Malaysia, Bangi, Selangor, Malaysia. (Email: sivap02@gmail.com)

Abd Hair Awang, School of Social, Development and Environmental, National University of Malaysia, Bangi, Selangor, Malaysia. Email: hair@ukm.edu.my.
They should be Nigerian citizens between the ages of 18 and 35 years old, they should have finished secondary school education, university education, or learning a trade, they are searching for work or already working, they are leaving maternal family because of matrimonial or being selfsufficient [2].

Unemployment among youths as a worldwide challenge is more serious and defying in underdeveloped states than the industrialized states. The summary report based on the study for European states, it indicated the Czech Republic has the lowest percentage of unemployment rate among youths while Greece has the highest unemployment rate of youth unemployment within the Euro region. The records also show that lady joblessness was at 9.2 percent and man was at 8.9 percent [3].

Northern of Africa in 2015 partook 30 percent as its unemployment rate among young persons for male and 45 percent for lady youth unemployment percentage. The article added their condition was truly pitiful as a great total of these youths were not in education, employment, nor training (NEET) The condition in Tunisia and Egypt was bothersome too as youths or young individuals between the ages of 15 and 29 were not in educated, employment or training (NEET) [4].

In a similar report, it indicated South Africa at the beginning of 2013 had 25.20 percent as its youth unemployment rate, Kenya had 40 percent at the end of 2011 as percentage of unemployment among youth., and Ghana's percentage of joblessness among youths in 2012 was 11 percent, while Nigeria youth unemployment rate in 2014 was at 54 percent. [5].

Obtainable records indicate that the continent of African and their nations have the topmost rate of unemployment among youths' in the globe. In addition to the low rate of unemployment among youths within Europe states, it comes from their active strategies towards reduction of youth unemployment. This study is prompted by the worrisome situation of youth unemployment in Nigeria because available literature did not critically analyze the Nigerian situation. For this purpose, the article took a departure after the earlier research to assess the factors responsible for unemployment among youth in Nigeria.

\section{LITERATURE REVIEW}

\section{A Theoretical Frame Work}

This study adopted the theory of neo-liberalism in an attempt to describe the complication of unemployment among youths in Nigeria. Neo-liberalism is Marxist political 
economy theory that engages in economic practices. The theory suggests that human well-being could be best achieved through privatization as freedom would be granted to individuals for ownership of property for free market transactions and for rapid development of the society. The theory added that government should concentrate in providing enabling environment for the smooth and successful running of the aforesaid. Provision of infrastructures and security are part of the essentials of the enabling environment as proposed by the theory. Neoliberalism as a theory has in it an element of modernization with its root in economic transformation and capitalism. The implication of this is that the man that is involved and being used in economic activities would need to be transformed. This could be done through the normal educational processes of learning, or through a targeted orientation for the desire goals

The main assumption of the theory is the transfer of the nation economy leadership from the government to business-oriented persons or individuals to achieve greater efficiency while the government engages in pro-business strategies and supervisory measures to attract investments within and without [6].

The theory became a global one due to the advice of John Williamson, that International Monetary Fund (IMF), World Bank, and World Trade Organizations should attach the aims and objectives of neo-liberalism as conditions to the financial assistance or loans for economic development to the developing states. It therefore became a governmental principle that is related along with global trade and industry and the growth of financial capitalism [7].

Nigerian government in 1986 adopted neo-liberalism as an economic policy by introducing Structural Adjustment Program (SAP). Her future was mortgaged and subjected to the absolute instructions of International Monetary Fund and acted based on such. At the ending of the 1980s, World Bank instructed Nigeria and other developing states that loaned out money to them to rationalize their public and civil service and they did. The result of that for Nigeria was thousands of its staff's appointment was terminated as its work force was reduced by $40 \%$. Majority of the people that were affected were young persons and women, and the economy was badly affected too as it had workable and energetic people that were disengaged from contributing their quota to the economic development of the country [8].

In his reaction to the adoption of neo-liberalism by Nigeria, and coupled with the high rate of youth unemployment, Mazrui attributed the unfortunate situation to Nigerian elites and the political class due to the acculturation they inherited from the colonial masters that made them elites of consumption instead of elites of investment and production, or of creation of jobs. The elites and the political class were not adequately equipped for creation of wealth and employment opportunities, and so the adoption of neo-liberalization could not see the light of the day. He, Mazrui concluded that the adoption of neoliberalization in Nigeria only created urbanization and not industrialization and as a result of this, Nigeria ended up of having a weak economy with massive youth unemployment [9].

From the discussion of the theory adopted to describe and elaborate on the difficulty of unemployment among youths in Nigeria and coupled with issues raised as regard to the implementation of the theory by Nigerian government in 1986, it has given adequate evidence that youth unemployment problem in Nigeria is attributed to Nigerian irresponsible leaderships. The elites and the political class have failed woefully in the management of Nigerian economic as lamented by [9]. The question one may ask in respect to neo-liberalism that is almost a global issue, and that most nations like Malaysia, USA, China, and many others that implemented and are excelling, why then Nigeria case is different? The answer is not far-fetched. One of the major essentials as a duty by government to make neoliberalism thrive is the provision of enabling environment. In this, infrastructures, security, and many more are embedded in what is regarded as enabling environment.

Nigerian leadership failed to provide the aforementioned for successful business transactions. The inability of Nigerian government to provide conducive atmosphere for economic engagements to thrive, coupled with the failure in electricity supply or power failure is responsible for youth unemployment in Nigeria. The activities of Boko Haram, kidnappings, herdsmen killings, corruption among the political class or public office holders have made the environment unsafe both for human beings and business engagements. It was reported that about one hundred business organizations folded up in Nigeria between 2009 and 2016 due to unfriendly nature of the environment [11].

Implementation of SAP in Nigeria was done out of pressure by the IMF and the World Bank, the elites and the political class were not prepared for it. This could be either they must have foreseen and were scared of the negative effects of implementing SAP in Nigeria or they were not well equipped for its implementation. Conditions given by the IMF and the World Bank for instance, the rationalization of the labor force, depreciation of Nigerian currency were both harsh and damaging to Nigerian economy. Numerous working age young persons were laid off either through retrenchment or their industries closed down due to the harsh environment created by the implementation of SAP. Devaluation of naira created serious problems both for the economy and the citizens. First, it led to high rate of inflation and reduction of the purchasing power of people, and this directly affected production industries as demands for their goods and services were drastically affected due to the inability of people to buy as it was.

\section{$B$ Youth unemployment trends in Nigeria}

The number of youth unemployment trends is carefully shown below to point out the increasing nature of youth unemployment in Nigeria for the past years.

Table- 1: National youth unemployment by gender

[21]

\begin{tabular}{|l|l|c|}
\hline \multirow{2}{*}{ Year } & \multicolumn{2}{|c|}{ Percentage of Unemployed Youths } \\
\cline { 2 - 3 } & Female & Male \\
\hline 2008 & 58.50 & 41.50 \\
\hline
\end{tabular}

Published By: 


\begin{tabular}{|l|l|l|}
\hline 2009 & 57.82 & 42.50 \\
\hline 2010 & 54.52 & 45.48 \\
\hline 2011 & 50.85 & 49.15 \\
\hline 2012 & 55.42 & 44.58 \\
\hline
\end{tabular}

As indicated on the above figures on this table, it indicates unemployment rate for young ladies is greater than those of the male colleagues. This may well be accredited to traditional conditions, matrimonial, and personal philosophy that could limit young ladies for accepting to go in for several employments.

Table- II: Graduate youth unemployment by resident [21]

\begin{tabular}{|l|l|l|l|}
\hline Year & $\begin{array}{c}\text { Ru } \\
\text { ral }\end{array}$ & Urban & Total \\
\hline 2003 & $8,3 \%$ & $17.3 \%$ & $25.6 \%$ \\
\hline 2004 & 12.8 & 25.2 & 38 \\
\hline 2005 & 13.3 & 19.0 & 32.3 \\
\hline 2006 & 13.4 & 18.8 & 32.2 \\
\hline 2007 & 13.4 & 18.7 & 32.1 \\
\hline 2008 & 21.7 & 15.8 & 27.5 \\
\hline 2009 & 19.8 & 19.2 & 39 \\
\hline 2010 & 20.7 & 22.8 & 43.5 \\
\hline 2011 & 25.6 & 17.1 & 42.7 \\
\hline
\end{tabular}

Table II has the statistics of graduate youth unemployment by resident (urban/rural) for 2003 to 2011. The urban and rural are separated to point out the differences and where it was more serious. Within the period of this statistics, urban graduate youth unemployment was higher than their counterparts in the rural areas. The reason could be the migration of young persons from their rural areas to cities with the belief there are better employment opportunities there, coupled with the availability of infrastructures.

Table- III: Youth unemployment rate by states in Nigeria: 2004-2011 [23]

\begin{tabular}{|c|c|c|c|c|c|c|c|c|}
\hline State & $\mathbf{2 0 0}$ & $\mathbf{2 0 0}$ & $\mathbf{2 0 0}$ & $\mathbf{2 0 0}$ & $\mathbf{2 0 0}$ & $\mathbf{2 0 0}$ & $\mathbf{2 0 1}$ & $\mathbf{2 0 1}$ \\
& $\mathbf{4}$ & $\mathbf{5}$ & $\mathbf{6}$ & $\mathbf{7}$ & $\mathbf{8}$ & $\mathbf{9}$ & $\mathbf{0}$ & $\mathbf{1}$ \\
\hline Abia & 6.5 & 7.9 & 14.7 & 11.9 & 15.5 & 15.5 & 17.5 & 13.2 \\
\hline Adamawa & 15.6 & 22.4 & 18.5 & 12.9 & 30.3 & 30.4 & 34.4 & 19.4 \\
\hline A/Ibom & 13.3 & 15.4 & 16.2 & 14.5 & 35.1 & 35.1 & 37.1 & 19.4 \\
\hline Anambra & 8.4 & 8.7 & 12.8 & 12.8 & 17.8 & 17.8 & 18.8 & 13.2 \\
\hline Bauchi & 23.2 & 27.6 & 24.9 & 8.3 & 38.2 & 38.2 & 40.2 & 44.4 \\
\hline Bayelsa & 13.2 & 23.9 & 15.2 & 8.9 & 39.4 & 39.4 & 40.4 & 25.9 \\
\hline Benue & 9.8 & 15.6 & 11.8 & 6.4 & 9.5 & 9.5 & 10.5 & 17.2 \\
\hline Borno & 4.7 & 6.3 & 4.3 & 8.8 & 28.7 & 28.7 & 30.7 & 30.1 \\
\hline C/River & 12.3 & 14.1 & 17.9 & 12.8 & 15.3 & 15.3 & 16.3 & 19.2 \\
\hline Delta & 9.9 & 5.5 & 14.8 & 19.9 & 19.4 & 19.4 & 22.8 & 29.2 \\
\hline Ebonye & 9.9 & 6.2 & 12.9 & 10.5 & 13.0 & 13.0 & 14.0 & 25.1 \\
\hline Edo & 7.6 & 9.7 & 9.6 & 6.1 & 13.2 & 13.2 & 15.0 & 27.1 \\
\hline Ekiti & 9.8 & 8.3 & 7.8 & 16.6 & 22.6 & 22.6 & 24.6 & 15.1 \\
\hline Enugu & 22.5 & 28.3 & 22.1 & 10.5 & 15.9 & 15.9 & 17.9 & 29.2 \\
\hline Gombe & 14.3 & 23.8 & 18.4 & 11.5 & 33.1 & 33.1 & 36.1 & 39.7 \\
\hline Imo & 17.4 & 17.5 & 21.4 & 8.6 & 22.8 & 22.8 & 24.8 & 38.9 \\
\hline Jigawa & 20.9 & 19.1 & 22.7 & 18.4 & 25.5 & 27.5 & 29.5 & 38.9 \\
\hline Kaduna & 17.7 & 14.1 & 15.7 & 6.9 & 10.6 & 13.6 & 14.6 & 33.3 \\
\hline Kano & 23.4 & 18.1 & 20.4 & 13.7 & 28.6 & 28.6 & 30.6 & 24.3 \\
\hline Katsina & 23.3 & 24.8 & 20.3 & 6.8 & 38.3 & 38.3 & 30.3 & 30.1 \\
\hline Kebbi & 23.9 & 17.7 & 17.2 & 13.8 & 13.0 & 14.0 & 14.0 & 29.3 \\
\hline Kogi & 12.5 & 15.8 & 14.5 & 17.5 & 20.0 & 20.0 & 24.0 & 18.4 \\
\hline Kwara & 5.4 & 3.8 & 8.5 & 17.4 & 10.0 & 13.0 & 14.0 & 10.1 \\
\hline Lagos & 18.1 & 7.5 & 16.5 & 11.2 & 14.5 & 20.5 & 24.5 & 10.3 \\
\hline Nasarawa & 7.8 & 9.7 & 9.2 & 8.6 & 11.1 & 13.1 & 14.1 & 39.5 \\
\hline Niger & 4.5 & 2.2 & 7.6 & 18.0 & 11.9 & 14.9 & 15.9 & 41.4 \\
\hline Ogun & 2.9 & 3.5 & 4.3 & 5.9 & 9.5 & 9.5 & 10.5 & 25.9 \\
\hline & & & & & & & & \\
\hline
\end{tabular}

\begin{tabular}{|c|c|c|c|c|c|c|c|c|}
\hline Ondo & 7.8 & 7.2 & 7.7 & 7.8 & 16.9 & 18.9 & 19.9 & 15.5 \\
\hline Osun & 3.2 & 3.9 & 4.7 & 8.3 & 15.6 & 15.6 & 16.6 & 6.0 \\
\hline Oyo & 4.1 & 6.3 & 5.3 & 8.5 & 17.9 & 17.9 & 19.9 & 9.9 \\
\hline Plateau & 3.6 & 4.8 & 4.9 & 97 & 9.1 & 9.1 & 9.1 & 25.3 \\
\hline Rivers & 13.2 & 9.0 & 27.0 & 6.7 & 29.9 & 30.9 & 29.9 & 29.5 \\
\hline Sokoto & 5.5 & 7.1 & 7.4 & 17.1 & 27.4 & 27.4 & 28.4 & 19.9 \\
\hline Taraba & 14.6 & 5.4 & 16.0 & 7.9 & 29.8 & 29.8 & 29.8 & 16.7 \\
\hline Yobe & 13.7 & 9.0 & 15.6 & 19.9 & 29.3 & 29.3 & 30.3 & 39.6 \\
\hline Zamfara & 7.3 & 9.1 & 45.8 & 15.8 & 18.3 & 18.3 & 18.3 & 45.6 \\
\hline FCT & 7.9 & 9.5 & 19.4 & 18.4 & 25.5 & 26.5 & 29.5 & 24.1 \\
\hline Nigeria & 15.4 & 15.9 & 17.7 & 17.6 & 22.7 & 19.7 & 25.5 & 26.9 \\
\hline
\end{tabular}

Table III as indicated above has the statistics of youth unemployment rates by states. It shows the progressive nature of youth unemployment in Nigeria between 2004 and 2011. From the presented statistics, youth unemployment in Nigeria was higher in Bauchi, Delta, Kano, Katsina, and Zamfara states between 2002 and 2010. In 2011 as indicated above, youth unemployment was more severe in Bauchi, Borno, Edo, Gombe, Imo, Jigawa, Kaduna, Katsina, Nasarawa, Niger, Yobe, and Zamfara states than other states of the nation. With a careful analysis of the statistics, it indicated youth unemployment in Nigeria was growing up rapidly. This could be attributed to insecurity and the deteriorated nature of infrastructures in Nigeria that led to the migration of many business organizations between 2009 and 2016 [11].

\section{METHODOLOGY}

This study adopted qualitative as its methodology and applied descriptive nature in the application of this research. The research relied fully on secondary data as its major sources. A few of these were being drawn from published sources and unpublished such as journals, books, periodical reports from recognized international organizations like the ILO and NBS. Others are from the World Bank, CBN, OECD and newspapers. Meticulous and earnest literature review was greatly engaged on the subject matter on youth, unemployment and its causes as it relates to some nations of the world, but with much emphasis on Nigeria. This was purposively done to verify sources of data before their usage in this study.

\section{RESULTS AND DISCUSSION}

Based on the records obtained from secondary sources and as revealed through methodology of this study, it shows some causes of unemployment among youths in Nigeria in the following ways as discussed below. Nigerian unemployment among youths is a result of chains of factors. They are thus: Corruption, insecurity, neglect of agriculture, misguided educational qualifications, and lack of enabling environment for businesses.

\section{A Fraud}

Fraud or corruption is considered as criminal practices and unlawful behaviors or undertakings with the intention to obtain material goods or incomes meant for the public or the society [12]. Dishonesty or corruption is then the most accountable for Nigerian unemployment among youths as it

Blue Eyes Intelligence Engineering

\& Sciences Publication 
is the morally wrong or prohibited engagements of people at the administration of our wealth that brought nation to this degrading level of high unemployment among youths in Nigeria. In this, officials or officers who are lawfully employed for the advantageous of the society, use their lawful or official bureaus or positions for private advantage. These in most cases engage in embezzlement of society fund supposed or required for developmental purposes and creation of work prospects. This unlawful way of such bureaucrats could engage in falsifications of records and data and to favor some individuals in its place of remaining impartial in the fulfilment of their duties as specified by the civil service guidelines that public officials ought to remain unbiased in managing official appointed responsibilities [11]. Corruption or fraud as an unlawful way of stealing what goes to others, particularly the overall society is also being in carry out by those in private sector in Nigeria. Tax avoidance and tax averting has been their main engagement in corruption, and this is best defined as dishonest method of paying taxes to government as chains of processes are been applied in this fraudulent act. The real meaning of this is to amass much money for themselves and their companies. The harmful effect of this fraudulent actions of paying less taxes or non to government, robs the government of the enough resources that is needed for the community expansion and establishment of infrastructures and creation of work opportunities [13].

Table- IV: Economic and Financial Crimes

Commission (EFCC) profile cases 2000 - 2010

\begin{tabular}{|c|c|c|c|c|}
\hline $\mathbf{S} / \mathbf{N}$ & Name & $\begin{array}{c}\text { Case } \\
\text { Status } \\
\end{array}$ & $\begin{array}{l}\text { Amount } \\
\text { Involved }\end{array}$ & $\begin{array}{c}\text { Status } \\
\text { Suspect(s) }\end{array}$ \\
\hline 1 & $\begin{array}{c}\text { Ayo Fayose } \\
\text { Governor Ekiti State }\end{array}$ & $\begin{array}{c}\text { Arraigned } \\
\text { on } 51 \\
\text { counts }\end{array}$ & $\mathrm{N} 1.2 \mathrm{~b}$ & $\begin{array}{c}\text { Case } \\
\text { pending, . }\end{array}$ \\
\hline 2 & $\begin{array}{l}\text { Adenike, G former } \\
\text { Minister of Health }\end{array}$ & $\begin{array}{l}\text { Arraigned } \\
\text { on } 56 \\
\text { counts }\end{array}$ & $\mathrm{N} 300 \mathrm{~m}$ & $\begin{array}{c}\text { Discharged } \\
\text { and acq }\end{array}$ \\
\hline 3 & $\begin{array}{l}\text { Joshua D Governor } \\
\text { Plateau state }\end{array}$ & $\begin{array}{l}\text { Arraigned } \\
\text { on } 23 \\
\text { counts }\end{array}$ & $\mathrm{N} 700 \mathrm{~m}$ & $\begin{array}{c}\text { Case } \\
\text { pending, }\end{array}$ \\
\hline 4 & $\begin{array}{c}\text { Saminu Turaki } \\
\text { Governor Jigawa } \\
\text { state }\end{array}$ & $\begin{array}{c}\text { Arraigned } \\
\text { on } 32 \\
\text { counts }\end{array}$ & N36 b & $\begin{array}{c}\text { Case } \\
\text { pending, }\end{array}$ \\
\hline 5 & $\begin{array}{c}\text { Oji Uzor Kalu } \\
\text { Governor Abia state }\end{array}$ & $\begin{array}{l}\text { Arraigned } \\
\text { on } 107 \\
\text { state counts }\end{array}$ & $\mathrm{N} 5 \mathrm{~b}$ & $\begin{array}{c}\text { Case } \\
\text { pending, }\end{array}$ \\
\hline 6 & $\begin{array}{c}\text { James IGovernor } \\
\text { Delta state }\end{array}$ & $\begin{array}{l}\text { Arraigned } \\
\text { on } 170 \\
\text { counts }\end{array}$ & N9.2 b & $\begin{array}{c}\text { Case } \\
\text { pending, }\end{array}$ \\
\hline 7 & $\begin{array}{c}\text { Iyabo Obasanjo } \\
\text { Senator }\end{array}$ & $\begin{array}{l}\text { Arraigned } \\
\text { on } 56 \text { state } \\
\text { counts }\end{array}$ & $\mathrm{N} 10 \mathrm{~m}$ & $\begin{array}{c}\text { Case } \\
\text { pending, }\end{array}$ \\
\hline 8 & $\begin{array}{c}\text { LuckyIgbinedion } \\
\text { Governor of Edo } \\
\text { state. }\end{array}$ & $\begin{array}{c}\text { Arraigned } \\
\text { on } 191 \\
\text { state counts }\end{array}$ & $\mathrm{N} 4.3 \mathrm{~b}$ & $\begin{array}{c}\text { Case } \\
\text { determined, } \\
\text { ordered to } \\
\text { pay } \$ 25 \mathrm{~m} .\end{array}$ \\
\hline 9 & $\begin{array}{c}\text { Gabriel Aduku } \\
\text { Minister of Health }\end{array}$ & $\begin{array}{l}\text { Arraigned } \\
\text { on } 56 \text { state } \\
\text { counts }\end{array}$ & $\mathrm{N} 300 \mathrm{~m}$ & $\begin{array}{l}\text { Discharged } \\
\text { \& acq. }\end{array}$ \\
\hline 10 & $\begin{array}{c}\text { Jolly N Governor of } \\
\text { Taraba state. }\end{array}$ & $\begin{array}{c}\text { Arraigned } \\
\text { on } 41 \text { state } \\
\text { counts }\end{array}$ & $\mathrm{N} 1.3 \mathrm{~b}$ & $\begin{array}{c}\text { Case } \\
\text { pending, }\end{array}$ \\
\hline 11 & $\begin{array}{c}\text { Chimaroke } \mathrm{N} \\
\text { Governor of Enugu } \\
\text { state }\end{array}$ & $\begin{array}{c}\text { Arraigned } \\
\text { on } 105 \\
\text { state counts }\end{array}$ & $\mathrm{N} 5.3 \mathrm{~m}$ & $\begin{array}{c}\text { Case } \\
\text { pending, }\end{array}$ \\
\hline 12 & $\begin{array}{l}\text { Michael Botmang } \\
\text { (former Governor of }\end{array}$ & $\begin{array}{l}\text { Arraigned } \\
\text { on } 31 \text { state }\end{array}$ & $\mathrm{N} 1.5 \mathrm{~b}$ & $\begin{array}{c}\text { Case } \\
\text { pending, }\end{array}$ \\
\hline
\end{tabular}

\begin{tabular}{|c|c|c|c|c|}
\hline & Plateau state) & counts & & \\
\hline 13 & $\begin{array}{l}\text { Roland Iyayi former } \\
\text { MD of FAAN }\end{array}$ & $\begin{array}{l}\text { Arraigned } \\
\text { on } 11 \text { state } \\
\text { counts } \\
\end{array}$ & $\begin{array}{c}\text { N5.6 } \\
\text { billion }\end{array}$ & $\begin{array}{c}\text { Case } \\
\text { pending, . }\end{array}$ \\
\hline 14 & $\begin{array}{c}\text { Prof. Babalola } \\
\text { Borishade Minister } \\
\text { of Aviation }\end{array}$ & $\begin{array}{c}\text { Arraigned } \\
\text { on } 11 \text { state } \\
\text { counts } \\
\end{array}$ & $\begin{array}{l}\mathrm{N} 5.6 \\
\text { billion }\end{array}$ & $\begin{array}{c}\text { Case } \\
\text { pending, }\end{array}$ \\
\hline 15 & $\begin{array}{c}\text { Boni H Governor of } \\
\text { Adamawa state. }\end{array}$ & $\begin{array}{l}\text { Arraigned } \\
\text { on } 28 \text { state } \\
\text { counts } \\
\end{array}$ & $\begin{array}{l}\mathrm{N} 254 \\
\text { million }\end{array}$ & $\begin{array}{c}\text { Case } \\
\text { pending, }\end{array}$ \\
\hline 16 & Bode George & $\begin{array}{l}\text { Arraigned } \\
\text { on } 68 \text { state } \\
\text { counts }\end{array}$ & $\mathrm{N} 100 \mathrm{~b}$ & $\begin{array}{l}\text { Jailed in } \\
2009 .\end{array}$ \\
\hline 17 & $\begin{array}{l}\text { Rasheed L Governor } \\
\text { of Oyo state) }\end{array}$ & $\begin{array}{c}\text { Arraigned } \\
\text { on } 33 \text { state } \\
\text { counts }\end{array}$ & N6 b & $\begin{array}{c}\text { Case } \\
\text { pending, }\end{array}$ \\
\hline 18 & $\begin{array}{l}\text { Senator Nichola } \\
\text { Ugbane; Hon. } \\
\text { Elumelu. }\end{array}$ & $\begin{array}{c}\text { Arraigned } \\
\text { on } 158 \\
\text { state counts }\end{array}$ & $\mathrm{N} 5.2 \mathrm{~b}$ & $\begin{array}{c}\text { Case } \\
\text { pending, }\end{array}$ \\
\hline 19 & $\begin{array}{l}\text { Hamman Bello } \\
\text { Hammed . }\end{array}$ & $\begin{array}{c}\text { Arraigned } \\
\text { on } 46 \text { state } \\
\text { counts } \\
\end{array}$ & $\mathrm{N} 2.5 \mathrm{~b}$ & $\begin{array}{c}\text { Case } \\
\text { pending, }\end{array}$ \\
\hline 20 & $\begin{array}{l}\text { Adamu Abdullahi } \\
\text { Governor of } \\
\text { Nasarawa state }\end{array}$ & $\begin{array}{l}\text { Arraigned } \\
\text { on } 149 \\
\text { count } \\
\text { charge } \\
\end{array}$ & $\mathrm{N} 15 \mathrm{~b}$ & $\begin{array}{c}\text { Case } \\
\text { pending }\end{array}$ \\
\hline 21 & $\begin{array}{c}\text { Attahiru Bafarawa } \\
\text { Governor of Sokoto } \\
\text { state }\end{array}$ & $\begin{array}{c}\text { Arraigned } \\
\text { on } 47 \text { count } \\
\text { charge }\end{array}$ & N15 b & $\begin{array}{c}\text { Case } \\
\text { pending }\end{array}$ \\
\hline 22 & $\begin{array}{c}\text { Hassan Lawal } \\
\text { Minister of Works }\end{array}$ & $\begin{array}{c}\text { Arraigned } \\
\text { on } 37 \text { count } \\
\text { charge }\end{array}$ & N75 b & $\begin{array}{c}\text { Case } \\
\text { pending,. }\end{array}$ \\
\hline 23 & Kenny Martins & $\begin{array}{l}28 \text { count } \\
\text { charge }\end{array}$ & $\mathrm{N} 7,740 \mathrm{~b}$ & $\begin{array}{c}\text { Case } \\
\text { pending, }\end{array}$ \\
\hline 24 & $\begin{array}{c}\text { Esai Dangabar, Atiku } \\
\text { Abubakar Kigo, } \\
\text { Ahmed Inuwa Wada, } \\
\text { John Yakubu Yusufu, } \\
\text { Mrs. Veronica } \\
\text { Ulonma Onyegbula } \\
\text { and Sani Habila Zira } \\
16\end{array}$ & $\begin{array}{l}16 \text { count } \\
\text { charge }\end{array}$ & $\mathrm{N} 32.8 \mathrm{~b}$ & $\begin{array}{c}\text { Case } \\
\text { pending, }\end{array}$ \\
\hline
\end{tabular}

Table IV is the statistics of the few among the many cases of corruption among the political or public office holders in Nigeria. The painful thing with this destructive condition is that most of these people are currently serving as senators and holding appointed highly and influential positions in this present government of President Muhammadu Buhari. The implication of this could be the entire system and leadership is corrupt, or else why thieves are honored with leadership positions instead of bringing them to book as deterrent to others and at the same time correcting the ills in the society.

\section{B Security problems}

The security problems in Nigerian too is a major factor accountable for unemployment among youths. The earnestness of this began with explosive or explosion of bombs in Abuja during Nigeria independence of of 2010. Later, quite a lot of bombs and its explosions were carried out in numerous cities and towns within Nigeria as a nation and of course in difference worship accommodations, trading apartments and motor or car garage. Several people died, a lot of businesses as well possessions of people worth

Published By:

Blue Eyes Intelligence Engineering

\& Sciences Publication 
of uncountable amount of naira have being damaged. A good percentage of business was unable to last longer than the unfortunate occurrences and the consequence was that the employees became jobless and it creased unemployment rate [15].

As the state of affairs therefore raised the total of jobless among young persons and illegal activities between them by way of several of them went into social ills, while so many got employed into religious fanaticism and kidnapping. Several were involved and tempted into tribal and religious disaster and some went into other associated crimes [14]. Several international business people moved away to other nations where these persons knew the nations had better and adequate peace and safety and due to this, numerous Nigerians became unemployed. While when the explosions of bomb, abductions of people and other criminalities was increasing or triumphing in Nigerian, the condition of insecurity provoked some countries that had companies within Nigeria to give out peculiar instructions for their nationals in Nigeria not and where to go in Nigeria for the terror and fears that these nationals could be preys of explosion of bomb or being abducted. US directed its peoples within its Department of Consular Activities in 2012 not to move to some specific places in Nigeria such as the states within the Niger Delta, the states within the south east of the nation, Plateau, Bauchi, and Borno states. This was due to numerous bomb explosions, abductions and the connected crimes [15]. It was stated that around 2009 and 2011 above 140 foreign persons were abducted by Nigerian young men. Their actions destroyed other companies that had were in once doing well and added the total of joblessness among youths in Nigeria as the atmosphere was not protected for economic accomplishments and businesses, while numerous companies crumpled up and by way of a consequence many schools shut down in the NorthEastern of the nation [12].

Table- V: Attacks by Boko Haram Sect in Nigeria from 2009 to 2012

\begin{tabular}{|c|c|c|c|c|}
\hline $\mathbf{S} / \mathbf{N}$ & $\begin{array}{l}\text { Date of } \\
\text { Attack }\end{array}$ & $\begin{array}{c}\text { State of } \\
\text { Attack }\end{array}$ & Location of Attack & $\begin{array}{l}\text { People } \\
\text { killed }\end{array}$ \\
\hline 1 & 2009 & Yobe & Potiskum, & 4 \\
\hline 2 & 2018 & Plateau & Jos. & 300 \\
\hline 3 & 2010 & Abuja & Abuja & 12 \\
\hline 4 & 2010 & Plateau & Barkin Ladi, & 8 \\
\hline 5 & 2010 & Abuja & Mogadishu Abuja. & 10 \\
\hline 6 & 2011 & Borno & Maiduguri & 7 \\
\hline 7 & 2011 & Kaduna & Sandamu, at Rigasa & 2 \\
\hline 8 & $\begin{array}{c}\text { Mar. } \\
30, \\
2011\end{array}$ & Yobe & Damaturu. & 1 \\
\hline 9 & $\begin{array}{l}\text { April 8, } \\
2011\end{array}$ & Niger & Suleja & 8 \\
\hline 10 & $\begin{array}{c}\text { April } \\
26, \\
2011 \\
\end{array}$ & Bauchi & Bauchi & 3 \\
\hline 11 & $\begin{array}{l}\text { May } \\
29, \\
2011\end{array}$ & $\begin{array}{c}\text { Abuja } \\
\text { Bauchi } \\
\text { and Zaria }\end{array}$ & $\begin{array}{l}\text { Multiple bombings in } \\
\text { Northern Nigeria. }\end{array}$ & 13 \\
\hline 12 & $\begin{array}{c}\text { June } \\
7, \\
2011 \\
\end{array}$ & $\begin{array}{l}\text { Abuja and } \\
\text { Borno }\end{array}$ & $\begin{array}{l}\text { Abuja, Damboa town, } \\
\text { Maidugur }\end{array}$ & 5 \\
\hline 13 & $\begin{array}{l}\text { June } \\
16,\end{array}$ & $\begin{array}{l}\text { Abuja and } \\
\text { Borno. }\end{array}$ & $\begin{array}{c}\text {, Abuja, Damboa town, } \\
\text { Maiduguri }\end{array}$ & 7 \\
\hline
\end{tabular}

\begin{tabular}{|c|c|c|c|c|}
\hline & 2011 & & & \\
\hline 14 & $\begin{array}{c}\text { June } \\
20,201\end{array}$ & Kaduna & $\begin{array}{c}\text { Kankara Police station in } \\
\text { Katsina state. }\end{array}$ & 7 \\
\hline 15 & $\begin{array}{c}\text { July } 9, \\
2011\end{array}$ & $\begin{array}{l}\text { Borno and } \\
\text { Niger } \\
\text { states }\end{array}$ & $\begin{array}{c}\text { A clash between Boko } \\
\text { Haram and the military in } \\
\text { Maiduguri, Borno State, } \\
\text { also in Suleja, Niger State, } \\
\text { a bomb was targeted at a } \\
\text { church. }\end{array}$ & 35 \\
\hline 16 & 2011 & Borno & $\begin{array}{c}\text { Boko Haram threw an } \\
\text { explosive device on a } \\
\text { moving Military patrol } \\
\text { vehicle }\end{array}$ & $\begin{array}{l}5 \text { people } \\
\text { killed }\end{array}$ \\
\hline 17 & 2011 & Borno & Explosion in Maiduguri. & $\begin{array}{l}5 \text { people } \\
\text { injured }\end{array}$ \\
\hline 18 & 2011. & Maiduguri & Maiduguri. & 8 \\
\hline 19 & 2011 & Abuja & Abuja & 25 \\
\hline 20 & 2011 & Bauchi & Misau & 7 \\
\hline 21 & 2011 & Borno & Maidugur & 1 \\
\hline 22 & 2011 & Borno & Maiduguri & 3 \\
\hline 23 & 2011. & Yobe & Damaturu, & 150 \\
\hline 24 & ,2011 & Yobe & Gendam. & 7 \\
\hline 25 & 2011 & Plateau & Jos. & 80 \\
\hline 26 & 2011 & Niger & Madalla church. & 50 \\
\hline 27 & 2012 & $\begin{array}{c}2012 \\
\text { Adamawa }\end{array}$ & $\begin{array}{c}\text { Christ Apostolic Church } \\
\text { Mubi }\end{array}$ & 37 \\
\hline 28 & 2012 & Kano & Kano & 150 \\
\hline 29 & 2012 & Kano & Sabon Gari of Kano & None \\
\hline 30 & 2012 & Kano & Kano & 5 . \\
\hline 31 & 2012. & Kaduna & Easter Day & 38 \\
\hline 32 & 2012 & Kaduna & kaduna. & 12 \\
\hline 33 & 2012 & Kogi & Deeper Life Church & 19 \\
\hline
\end{tabular}

Table V has few of the attacks of Boko Haram in Nigeria between 2009 and 2012. These attacks had made Nigeria environment highly in secured.

\section{Abandonment of agriculture}

Farming of different types provides equally food then employment to Nigeria society within the period of 1960s, but was deserted at 1970s as result of oil sector [11]. Agriculture ever prior to discovery of the oil sector engaged beyond 90 out of a hundred of Nigerian people as their key economy, then there was no unemployment and youths' problem or very minor, as almost had something doing or all were working-class individuals and were indeed vigorously involved in an agricultural activity or doing others related to agriculture to earn a living. The agricultural activities were later abandoned as a result of oil sector in Nigeria that had yielded abundant revenue but the oil sector was very inadequate to provide employment opportunities to Nigeria unemployed youths. As result to Nigeria's bad mindsets towards agriculture, the said agriculture could not grow as it should since there remain no policies through to that effect, and together with Nigeria low stage of technology as an issue responsible for its low development as numerous farming endeavors are still done without mechanized system as attainable in other parts of the advanced and other countries. In challenging with unemployment among youths, Nigerian farming sector should be reorganized to 
comfortably appeal and engage the great populace of the jobless young people.

\section{Erroneous and Outed Education}

Erroneous educational credentials play a main reason to unemployment among youths in Nigeria. Cause for this is that Nigerian youths are not sufficiently directed and guided on the programs and curricula they went in to study in their several institutions of studying. As a consequence of this, the employment or work necessities are not take into consideration according to the changing world and global requirements. These youths have their scholastic credentials but they not have prerequisite skills wanted for the work as required by companies and employers of labor at this generation and dispensation or age. Additional cause is that the syllabus for the educational organizations are outdated as per it has not and doesn't in most insistences comprise employment useful skills, added to this, almost Nigerian educational establishment are not sufficiently equipped for the desirable skills according to the prerequisite for work in this present-day dispensation [16].

In their persuasion for job-related and mechanical education and acquisition skills as solution for unemployment, among youths, few scholars stated its importance as thus: that it has the enablement for contending with unemployment and poverty through skills acquisition for development in a given society.

That the chief task of job-related and mechanical education acquisition skills is that it furnishes the youths with the preferred skills for self-reliance and to facilitates them appropriately contribute in the progressive procedures of their countries [17], [19]. Furthermore, to the above explanations of unemployment among youths, a researcher detailed it clearer that the rising unemployment rate among enormous number of young persons do not have the abilities to start and manage a trade so as to become entrepreneurial.

\section{E Lack of Supporting Environment}

Nigeria atmosphere is not certainly secure for any sensible economic engagements neither does it makes it appealing to foreign business people any further due to actions of Boko Haram, then other criminal tendencies performances. It was stated that several business organizations in Nigeria that provided work for great number of Nigerians closed down within 2009 and 2016 as a result of the uncertainty condition of the atmosphere as specified above and as result scarcity of electricity power supply. The shutting down of some of the commercial establishments in Nigeria in these years immediately made their staff that were in thousands unemployed [11], [20]. The poor nature of power supply and lack of infrastructures to help the youths in their struggles to remain in their enterprises intensified to extend the self-employed or entrepreneurial young persons closed down their business engagements as they were unable to purchase their individual power generators [18]. Other foreign business establishments also had similar difficulties like the Nigerian self-employed youths, and they too closed up and left for other nations. The closure of the foreign business establishments added over two thousand unemployed youths in Nigeria is a sign or manifestation that the

persons to the existing great number of unemployed persons in Nigeria, especially the youths.

Table- VI: Summary of available crime statistics in Nigeria from 2000 to 2008 [24]

\begin{tabular}{|c|c|c|c|c|c|}
\hline Year & Theft & $\begin{array}{c}\text { Armed } \\
\text { Robbery }\end{array}$ & Kidnapping & Assassination & Fraud \\
\hline 2000 & 29127 & 1877 & 243 & 1255 & 7927 \\
\hline 2001 & 40796 & 2809 & 349 & 2120 & 10234 \\
\hline 2002 & 35231 & 3889 & 337 & 2117 & 9134 \\
\hline 2003 & 33124 & 3497 & 410 & 2136 & 9508 \\
\hline 2004 & 37289 & 3142 & 349 & 2550 & 9532 \\
\hline 2005 & 46111 & 2074 & 798 & 2074 & 9580 \\
\hline 2006 & 41901 & 2863 & 372 & 2000 & 6395 \\
\hline 2007 & 21082 & 2327 & 277 & 2007 & 5860 \\
\hline 2008 & 23927 & 2340 & 309 & 1956 & 5058 \\
\hline
\end{tabular}

Table VI has a summary of crime between 2000 and 2008. These are among the criminal engagements that have made Nigerian environment unconducive for economic activities to thrive.

\section{CONCLUSION}

Unemployment among youths indeed serves as a barrier to the growth of Nigeria and numerous countries of the world. It therefore demands serious consideration due to its consequences that is damaging the nation. Therefore, these submissions are put forward as channels for reducing the increasing rate of unemployment among youths in Nigeria.

Agriculture ought to be given a main concern by Nigerian leadership as it would feed and provide employment opportunities for the youths and the entire nation especially if modernized farming would be introduced like other states of the world.

A review of curricula in our educational institutions should be given a major concern. It should not only be restructured to equip young people with private enterprise and professional skills for self-sufficiency but the educational system that would equip the youths with all that they may require to comfortably face the changing environment and globalization.

The government/managers of public resources and policymakers should determine to be just and honest in the discharge of their responsibilities as this would help to significantly reduce the percentage of unemployment among youths and curtal corruption to its minimal level.

\section{REFERENCES}

1. A. Olawoyin, "Nigeria's unemployment worsens as 18.8\% are jobless," Premium Times, pp. 2017, 2019.

2. A. A. Abdullahi, D. S. Adekeye, and O. S. Balogun, "A'nation' in wilderness: Youth and insurgency in Nigeria," South African Rev. Sociol., vol. 45, no. 2, pp. 78-96, 2014.

3. A. A. Adebayo, "Implications of 'Boko Haram' terrorism on national development in Nigeria: A critical review,' Mediterr. J. Soc. Sci., vol. 5, no. 16, pp. 480-489, 2014.

4. C. Ehinomen and B. Afolabi, "Rising youth unemployment and its social economic implications for the growth and development of the Nigerian economy," SSRN Electron. J., 2015.

5. C. Fenwick, V. Van Goethem, C. Fenwick, and V. Van 
Goethem, "Labour market regulation and the imperative to stimulate job-rich growth,” Regul. Equitable Job-Rich Growth, pp. 1-28, 2018.

6. C. Osakwe and D. Ph, "Youth, unemployment and national security in Nigeria department of history and international studies," International Journal of Humanities and Social Science, vol. 3, no. 21, pp. 258268, 2013.

7. D. B. Adedeji, K. A. Soyinka, and O. M. Sunday, "Corruption control in the public sector and the Nigerian accountant," Int. J. Acad. Res. Accounting, Financ. Manag. Sci., vol. 8, no. 1, pp. 91-103, 2018.

8. E. Okafor, "Youth unemployment and implications for stability of democracy in Nigeria," J. Sustain. Dev. Africa, vol. 13, no. 1, pp. 358-373, 2011.

9. H. Dietrich, and J. Möller, "Youth unemployment in Europe-business cycle and institutional effects," International Economics and Economic Policy, vol. 13, no. 1, pp. 5-25, 2016.

10. I. A. Chiazor, "Unemployment in Nigeria: A time bomb waiting to explode: Issues, diagnoses and the way forward," Adv. Soc. Sci. Res. J., vol. 4, no. 1, pp. 2019 , 2017.

11. J. E. Edokpolor and R. O. Owenvbiugie, "Technical and vocational education and training skills: An antidote for job creation and sustainable development of Nigerian economy," Probl. Educ. 21st Century, vol. 75, no. 6, pp. 535-549, 2017.

12. J. Matunhu, "A critique of modernization and dependency theories in Africa: Critical assessment," African J. Hist. Cult., vol. 3, no. 5, pp. 65-72, 2011.

13. J. C. Brada, E. Marelli, and M. Signorelli, "Introduction: Young people and the labor market: Key determinants and new evidence," Comparative Economic Studies, vol. 56, no. 4, pp. 556-566, 2014.

14. M. Olatunji, "The goals of tertiary education: A philosophical assessment of Nigeria' S," vol. XX, no. 2, pp. 230-253, 2018.

15. Mcguinness, F. Youth Unemployment Statistics, 2017.

16. O. J. Otusanya, "The role of multinational companies in $\operatorname{tax}$ evasion and tax avoidance: The case of Nigeria," Crit. Perspect. Account., vol. 22, no. 3, pp. 316-332, 2011.

17. O. S. Adesina, "Unemployment and security challenges in Nigeria," Int. J. Humanit. Soc. Sci., vol. 3, no. 7, pp. 146-156, 2013.

18. T. Flew, "Six theories of neoliberalism," Thesis Elev., vol. 122, no. 1, pp. 49-71, 2014.

19. T. Karimova and E. E. Manrique, "Regulatory frameworks: Integration, partnerships and dialogue," World Employ. Soc. Outlook, vol. 2018, no. 2, pp. 71101, 2018.

20. T. R. Baker, "Internet-based GIS mapping in support of K-12 education," Prof. Geogr., vol. 57, , pp. 44-50, 2005.

21. Oduwole, Tajuden Adebowale. "Youth unemployment and poverty in Nigeria." International Journal of Sociology and Anthropology Research 1, no. 2 (2015): 23-39.

22. Ewetan, Olabanji Olukayode, and Ese Urhie. "Insecurity and socio-economic development in Nigeria." Journal of Sustainable Development Studies 5, no. 1 (2014).

23. Aiyedogbon, John O., and Bright O. Ohwofasa. "Poverty and youth unemployment in Nigeria, 1987-2011." International Journal of Business and Social Science 3, no. 20 (2012).

24. Achumba, I. C., O. S. Ighomereho, and M. O. M. AkporRobaro. "Security challenges in Nigeria and the implications for business activities and sustainable development." Journal of Economics and Sustainable Development 4, no. 2 (2013).

\section{AUTHORS PROFILE}

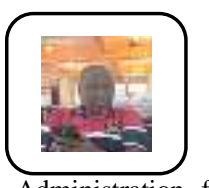

Galadima Gladstone Wayas is presently a $\mathrm{PhD}$ student in Development Science at the school of Social, Environment, and Developmental Studies, Faculty of Social Sciences and Humanities, Universiti Kebangsaan Malaysia. He has a Master degree in Publication Administration from Nasarawa state University Keffi, and a bachelor degree in Publication Administration from University of Jos in Plateau state. He has been working with Nasarawa state College of Education, Nigeria for the past 15 years.

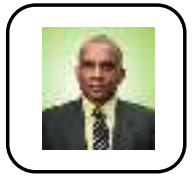

Prof. Dr Sivapalan Selvadurai is a lecturer with Universti Kebangsaan Malaysia for reasonable number of years at the school of Social, Environment, and Developmental Studies, Faculty of Social Sciences and Humanities. He has numerous publications to his credit and attended both international and local conferences. He is an ardent researcher on social and developmental issues with keen interest of providing solutions to developmental and social issues.

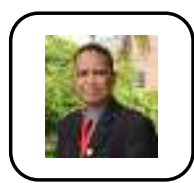

Prof. Dr Abd. Hair Awang lectures within the school of Social, Environment, and Developmental Studies, Faculty of Social Sciences and Humanities of Universiti Kebangsaan, Malaysia. As an old and experienced prof, he has contributed greatly to academic profession with numerous publications coupled with international and local conferences being attended by him. As a great researcher, he is bend on solving problems type of researches with the hope of providing solutions to societal challenges. 